\title{
Applications of Dredging and Beach Fills in GenCade
}

\section{US Army Corps} of Engineers

by Ashley E. Frey

PURPOSE: This Coastal and Hydraulics Engineering Technical Note (CHETN) provides guidance for simulating dredging of inlet shoals and associated placement of beach fills in GenCade. Applications of beach fills and dredging represent the majority of GenCade simulations and alternatives. This CHETN describes basic theory, setup, and applications of beach fills and dredging and is intended to explain how GenCade can be used to help District users answer questions about these types of applied engineering studies. Idealized applications of a single beach fill, an inlet with dredging and placement updrift and downdrift, and an inlet with dredging but sand removed from the model are described. Present model limitations are also discussed. The reader is referred to Frey et al. $(2012,2014)$ and Munger and Frey (2015) for additional information about the GenCade model.

INTRODUCTION: GenCade is a one-line shoreline change, sand transport, and inlet sandsharing model developed by the Coastal Inlets Research Program. It combines the project-scale, engineering design-level calculations of GENESIS (Hanson and Kraus 1989) and the regionalscale, planning-level calculations of Cascade (Larson et al. 2003; Connell and Kraus 2006). GenCade represents seawalls, groins, breakwaters, beach fills, sources and sinks, inlets and inlet shoals, and dredging events. GenCade is set up and run in two interfaces in the Surface-water Modeling System (SMS) 11.1 or higher; the first version of the model was released in 2012.

BEACH FILLS: A beach fill may be placed at any location along the beach. Multiple beach fills may occur sequentially at the same position, and several beach fills can exist at the same time in different locations. There are three assumptions related to the representation of beach fills in GenCade. First, the sand in the beach fill must have the same median grain size, $\mathrm{D}_{50}$, as the native sand (the $\mathrm{D}_{50}$ specified by the user in Model Control). Second, the profile of the fill represented in the model has the same equilibrium shape corresponding to its grain size, which means that the beach fill width specified by the user in the model is the width expected to develop after the filled beach has been equilibrated by waves and currents, not the width corresponding to the constructed fill template. Finally, the berm height of the nourished beach and the natural beach berm height are identical.

GenCade requires the modeler to input a beach fill as an added berm width instead of volume. After drawing an arc representing the shoreline length associated with the beach fill, the modeler should click on Select Feature Arc and double-click on the arc. A GenCade Arc Attributes window opens where a beach fill can be selected. After clicking Attributes, the user can specify the required start and end date, starting and ending cell, and the added berm width in meters (m) or feet ( $\mathrm{ft}$ ) (Figure 1). To convert the total fill volume to added berm width, the volume must be divided by the total alongshore distance and the active profile height (berm height plus depth of closure). It is simplest to think of a beach fill as a box where the length is the beach fill project length and the height is the distance between the berm height and the depth of closure. The added beach width is the total fill volume divided by the project length and the berm to depth of closure 
height. For example, consider a 250,000 cubic yards $\left(\mathrm{yd}^{3}\right)$ beach fill. The alongshore distance of the beach fill is $1,000 \mathrm{ft}$, and the active profile is $30 \mathrm{ft}$ in height. These values result in an added berm width of $225 \mathrm{ft}\left(\left(250,000 \mathrm{yd}^{3} * 27 \mathrm{ft}^{3} / 1 \mathrm{yd}^{3}\right) /(1,000 \mathrm{ft} * 30 \mathrm{ft})\right)$. If the fill volume per length of beach is given instead, say $250 \mathrm{yd}^{3} / \mathrm{ft}$ in this example $\left(250,000 \mathrm{yd}^{3} / 1000 \mathrm{ft}\right)$, the fill width is equal to this volume divided by the berm to closure depth, or $\left(250 \mathrm{yd}^{3} / \mathrm{ft}^{*} 27 \mathrm{ft}^{3} / 1 \mathrm{yd}^{3}\right)$ $/ 30 \mathrm{ft}=225 \mathrm{ft}$.

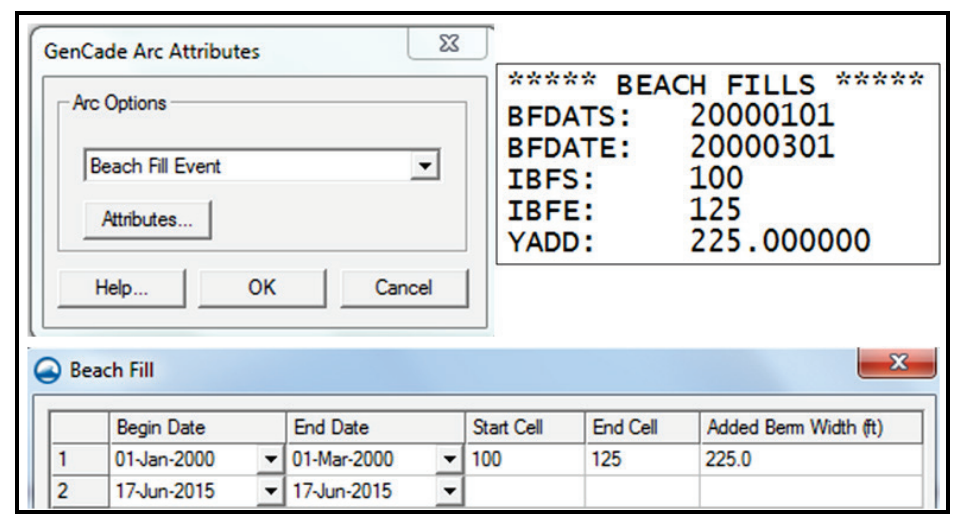

Figure 1. Top left: GenCade Arc Attributes menu. Bottom: Beach fill window in the SMS. Top right: Beach fill information in the *.gen file.

For a beach fill application, the shoreline is advanced an equal amount for each time-step at each cell where a fill has been defined, for the period of placement specified. In some cases, it may be necessary to have different berm widths along adjacent sections of the model. For example, a $300,000 \mathrm{yd}^{3}$ beach fill along 5,000 ft of beach might be adjacent to a 750,000 $\mathrm{yd}^{3}$ beach fill along another 5,000 ft stretch. If each cell is $50 \mathrm{ft}$ long, each beach fill will span 100 cells. If the active profile is $30 \mathrm{ft}$, the added berm width for the $300,000 \mathrm{yd}^{3}$ beach fill is $54 \mathrm{ft}$ while the added berm width of the second beach fill is $135 \mathrm{ft}$. Additional minor fills can be used to taper the ends of a major beach fill or to smooth the discontinuity between adjacent fills of different beach widths, although the model will smooth these shoreline discontinuities fairly rapidly. It is also possible for multiple beach fills to span a particular section of the shoreline at different times during the simulation. Therefore, a 250,000 $\mathrm{yd}^{3}$ beach fill along 2,500 ft of beach (added berm width $=90$ $\mathrm{ft}$ ) could be specified for a period 2 years after the first beach fill. A possible setup using the inputs is shown in Figure 2. Note that the events are rearranged according to the starting cell number so the final event starting in 2002 is listed before the second beach fill in 2000. Also, the starting and ending cells are included in the calculation for a beach fill. In the example, the first beach fill encompasses cells 100 to 199 or a total of 100 cells in length. To calculate the distance of the beach fill from this information, subtract the starting cell from the ending cell and add one, then multiple by the cell size.

\begin{tabular}{|c|c|c|c|c|c|c|c|}
\hline \multicolumn{8}{|c|}{ (2) Beach Fill } \\
\hline & Begin Date & & End Date & & Start Cell & End Cell & Added Berm Width (ft) \\
\hline 1 & 01Van-2000 & 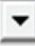 & 01-Feb-2000 & 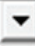 & 100 & 199 & 54.0 \\
\hline 2 & 01Van-2002 & 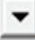 & 01-Feb-2002 & 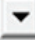 & 130 & 179 & 90.0 \\
\hline 3 & 01-Jan-2000 & 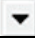 & 01-Feb-2000 & 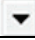 & 200 & 299 & 135.0 \\
\hline
\end{tabular}

Figure 2. Example beach fills. 
To see the impacts of a beach fill, a modeler should view the shoreline position (*.slo) file. The shoreline position at the end of the simulation may be compared to a no-action alternative to quantify the impacts of a beach fill.

DREDGING EVENTS: Dredging volumes are specified by the user. There are six inlet shoals in which dredging can be associated: ebb shoal, flood shoal, left and right attachment bars, and left and right bypassing bars. A dredging event in GenCade may last from 1 day (although unrealistic) to the full length of the simulation. Dredging events are added to the Inlet Reservoir Model, the submodel within GenCade that calculates inlet shoal evolution. After drawing an arc representing an inlet through the Create Feature Arc button, open the GenCade Arc Attributes window and select Inlet. Once the Attributes button is clicked, the Inlets window opens (Figure 3). Dredging can be managed through the Dredging Events window. The user must specify the beginning date, ending date, the shoal to be mined, and the volume ( $\left.\mathrm{yd}^{3} \mathrm{or}^{3}\right)$. The shoal will be mined uniformly, meaning that the volume will be divided by the number of time-steps so that the same volume is removed from the shoal at each time-step. This sand is completely removed from the model. Similar to beach fills, it is assumed that the sand in the shoals has the same $\mathrm{D}_{50}$ as the user specified for Median Grain Size. Material dredged from an inlet might be comprised of mixed sediments, so it is important to consider this when specifying a dredged volume. Finally, when the sand is removed from a shoal, the present volume of the shoal is a smaller percentage of the equilibrium volume than before dredging occurred. Therefore, more of the sand from longshore transport will deposit in the mined shoal compared to the same shoal without dredging. That sand is removed from longshore transport, and the downdrift beaches will likely experience more erosion than an identical inlet where the shoals are not dredged. More information about the theory of the Inlet Reservoir Model in GenCade is included in Frey et al. (2012, 2014). If the modeler would like the sand to be recycled as is common with Regional Sediment Management (RSM) practices, a beach fill with the same volume (or slightly less, if sand loss during the dredging and placement process is likely to occur) as the dredged volume should be added to the model.

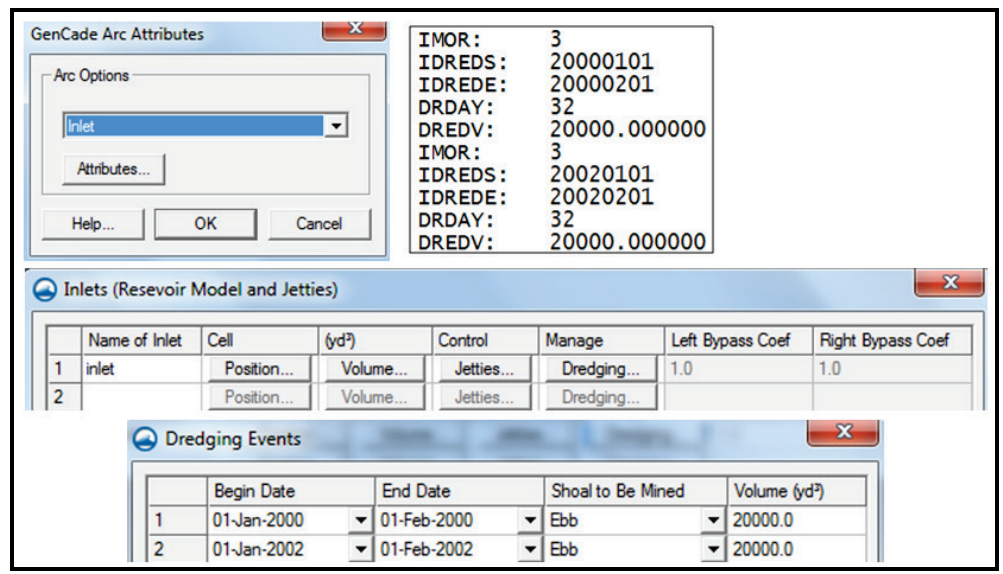

Figure 3. Top left: GenCade Arc Attributes menu. Top right: Dredging information in the *.gen file. Middle: Inlets window in the SMS. Bottom: Dredging events window in the SMS. 
To see the impacts of dredging on the shoal, the user should view the *.irv file for the specific inlet. This file lists the volume in each shoal and the transport between shoals for each userspecified time-step in the simulation. A graphic of the volume of each shoal through time can be viewed by going to Display->Plot Wizard and selecting GenCade Inlet TS. Click Next to specify the inlet, start time, and end time. The evolution through time can be shown for one or multiple shoals. It is recommended to view shoal evolution throughout the entire duration of the simulation. While this graphic is not a high-quality report figure, it can show whether the shoal is recovering from dredging or not (Figure 4). The impacts of inlet dredging on the downdrift shoreline can be seen by plotting the shoreline position. To plot the shoreline in SMS 11.1, drag the *.slo file into the project window or use File->Open. A user may view the shoreline position for each time-step through the simulation. In Figure 5, the red line is the initial shoreline, and green represents the calculated shoreline after 10 years. The GenCade grid is landward of the shorelines, so the body of water is toward the bottom of the window, or south, of the shorelines. Therefore, to the west of the inlet (the two blue lines along the shore), the shoreline is eroding.

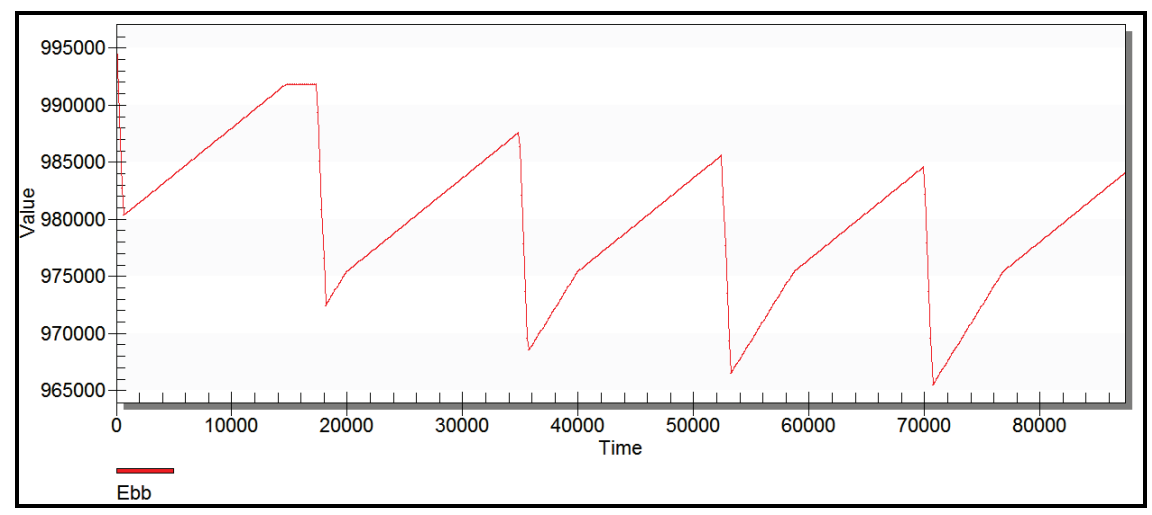

Figure 4. Ebb shoal evolution through time.

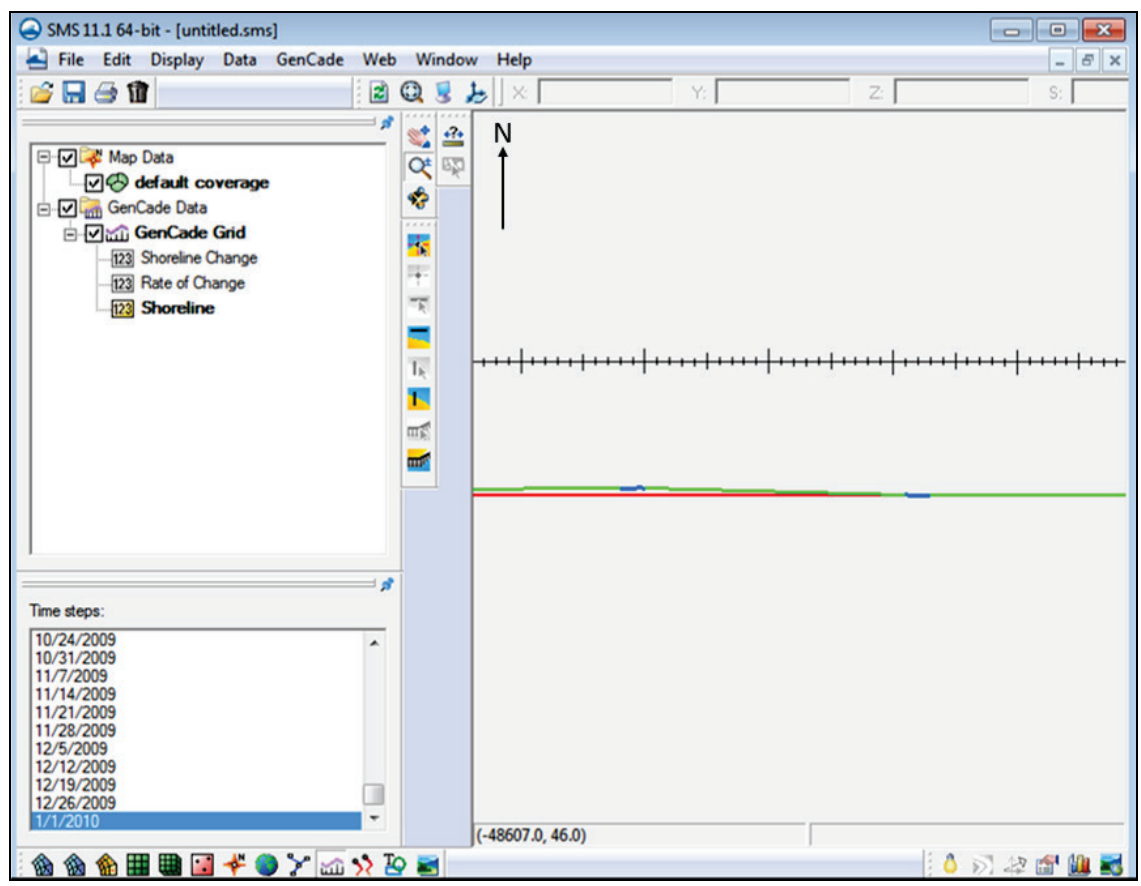

Figure 5. Shoreline position (green) compared to initial shoreline (red). 
APPLICATIONS: In order to illustrate the dredging and beach fill capabilities of GenCade, a number of different structured and nonstructured cases were run for 10 years and are analyzed herein. The following figures are meant to illustrate a qualitative conceptualization of processes. In all of the cases, the initial shoreline is straight. If no structures, beach fills, or inlets are added to the model, there is no regional contour, and there is a pinned lateral boundary condition, the shoreline would remain straight throughout the entire simulation. The waves are constant with a wave height of $0.75 \mathrm{~m}$, a wave period of 8 seconds, and a wave direction of $15^{\circ}$ shore normal. The berm height is $3 \mathrm{ft}$, and the depth of closure is $24 \mathrm{ft}$. The default settings were used for all of the other user-specified inputs.

Figure 6 compares an initial placement of $100,000 \mathrm{yd}^{3}\left(\right.$ or $\left.100 \mathrm{~K} \mathrm{yd}^{3}\right)$ to the periodic placement of $20,000 \mathrm{yd}^{3}$ every other year (five times which equals $100,000 \mathrm{yd}^{3}$ ). The length of each fill was $1,000 \mathrm{ft}$. This is an example of analysis comparing a relatively large beach fill placed at the beginning of a simulation to a smaller beach fill placed more often. The location of the beach fill is at 10 miles (mi) alongshore and is noted in black on the $x$-axis. After 10 years, the shoreline has advanced a maximum of $7 \mathrm{ft}$ for the initial $100,000 \mathrm{yd}^{3}$ beach fill while the $20,000 \mathrm{yd}^{3}$ placement every other year has resulted in a maximum shoreline advance of more than $10 \mathrm{ft}$. The shoreline impacts of the $100,000 \mathrm{yd}^{3}$ beach fill expands approximately $0.5 \mathrm{mi}$ farther in either direction than the $20,000 \mathrm{yd}^{3}$ every-other-year placement. The greater shoreline advance for the $20,000 \mathrm{yd}^{3}$ fill placed every other year compared to $100,000 \mathrm{yd}^{3}$ placed at the beginning of the simulation is to be expected because the $100,000 \mathrm{yd}^{3}$ fill has had a longer period of time to spread out along the $x$-axis. After many years, each beach fill will continue to spread across the entire domain, and the calculated shoreline will continue to straighten due to the perturbation. These results are shown to demonstrate the evolution of each beach nourishment practice in general terms. Please note that Figures 6-14 are vertically distorted; the horizontal axis is in miles while the vertical axis is in feet.

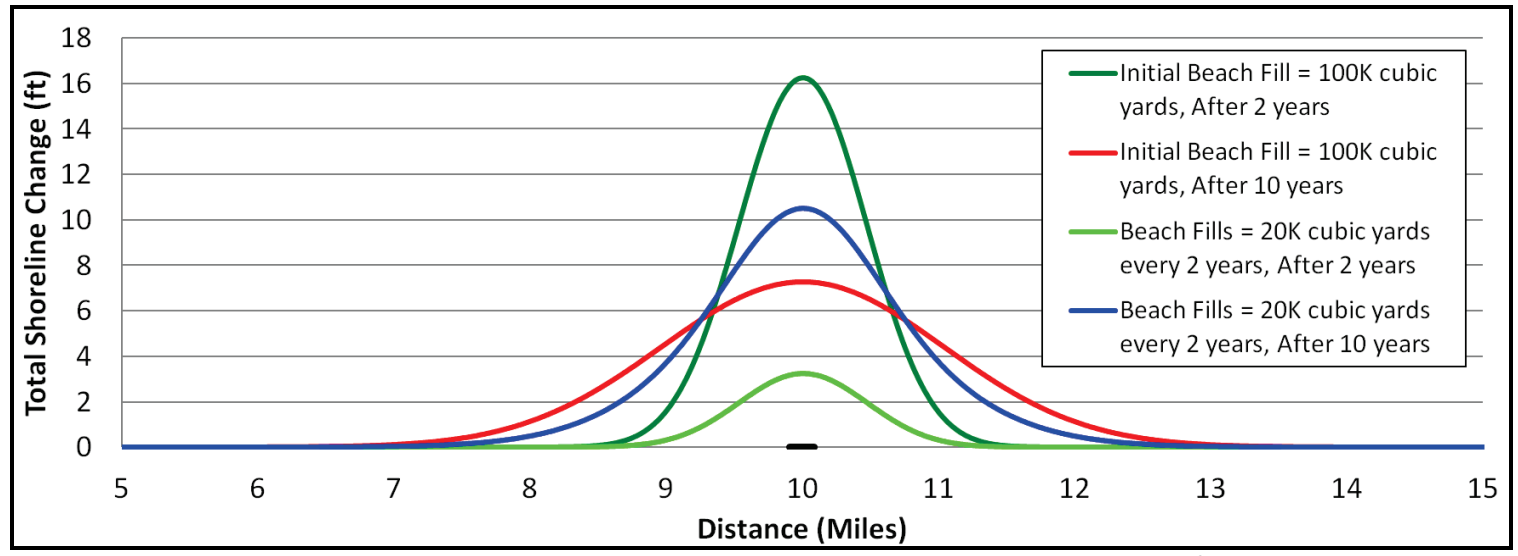

Figure 6 . Total shoreline change 10 years for beach fills placing 100,000 yd $\mathrm{d}^{3}$ initially and 20,000 $\mathrm{yd}^{3}$ every other year.

Figure 7 shows the same beach fill scenarios but includes a groin located directly to the left (updrift) of the beach fill. The groin has a porosity of 0.1 and is $240 \mathrm{ft}$ long. In these cases, the groin makes the largest impact, causing more than $150 \mathrm{ft}$ of accretion to the left and erosion to the right. Beach fills reduce the erosion by approximately $50 \mathrm{ft}$, but accretion is reduced by approximately $25 \mathrm{ft}$. The alternatives shown in Figure 6 are also shown in Figure 7 to illustrate how much more significant a groin is than a beach fill of $100,000 \mathrm{yd}^{3}$. 
In the beach fills section, it was mentioned that multiple beach fills can be added at the same time to represent nonuniform beach fills. Figure 8 compares the shoreline change of a nonuniform beach fill to a uniform beach fill. For the uniform case, the added berm width along the entire $1,000 \mathrm{ft}$ is $100 \mathrm{ft}$. The added berm width for the first $500 \mathrm{ft}$ of the nonuniform case is $150 \mathrm{ft}$ while the added berm width for the second $500 \mathrm{ft}$ is $50 \mathrm{ft}$, or 75,000 $\mathrm{yd}^{3}$ and 25,000 $\mathrm{yd}^{3}$, respectively. After 5 weeks, the nonuniform beach fill advances slightly more where the greater added berm width is located than the uniform case. Any perturbation caused by a nonuniform beach fill will diminish to an insignificant level through time, and this process will occur over a shorter period of time for a smaller project. At the end of a 10-year simulation, the calculated shoreline change is almost identical. For relatively small beach fills $\left(\sim 100,000 \mathrm{yd}^{3}\right)$, it might not be necessary to create a nonuniform beach fill, but differences between uniform and nonuniform beach fills should be noted when the beach fill volumes are larger.

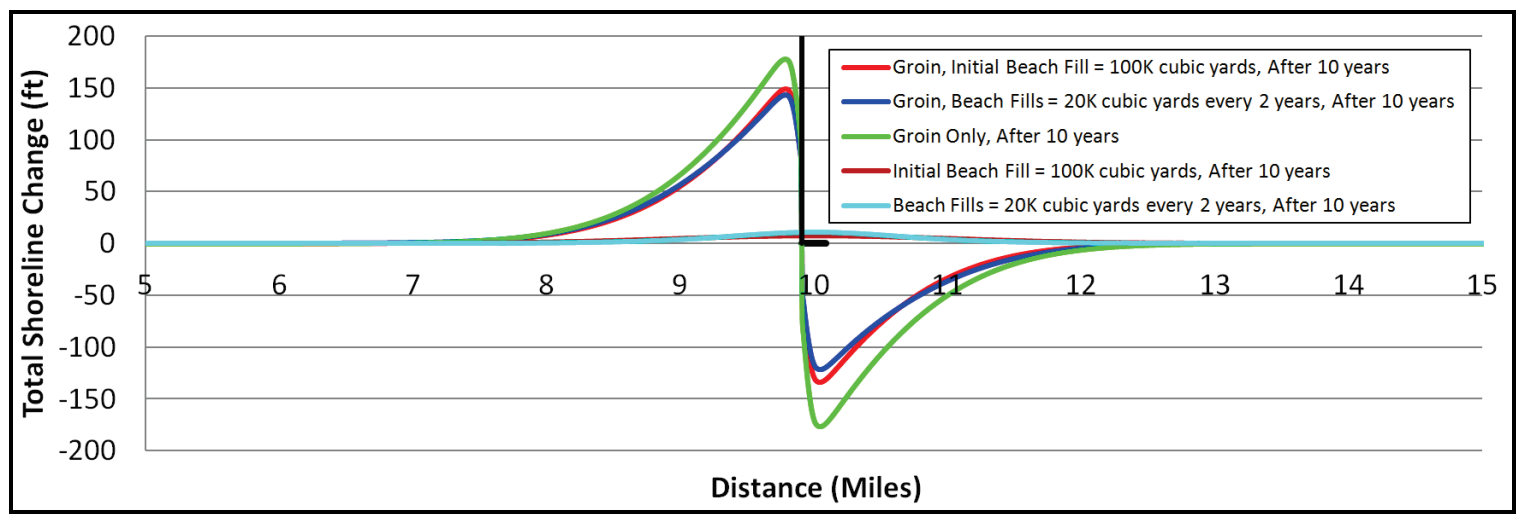

Figure 7. Total shoreline change after 10 years for beach fills (location of fill shown as black horizontal line on horizontal axis) placing $100,000 \mathrm{yd}^{3}$ initially and $20,000 \mathrm{yd}^{3}$ every other year. A groin is adjacent to the beach fill (black vertical line at $10 \mathrm{mi}$ ).

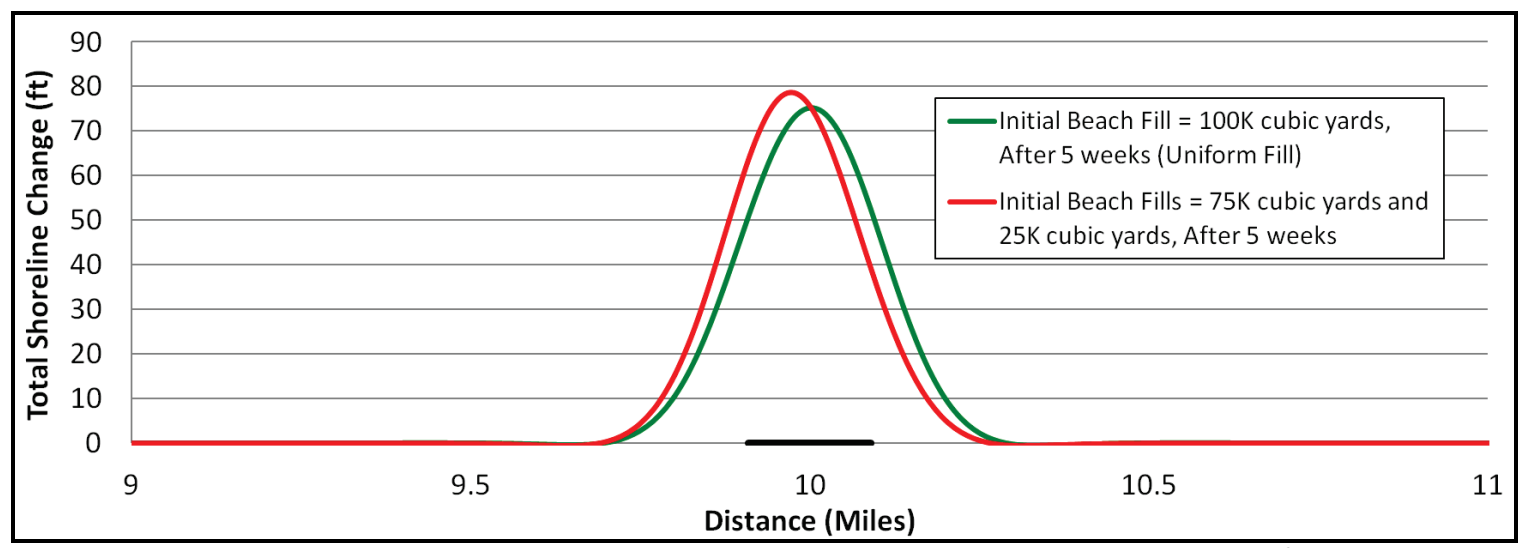

Figure 8. Total shoreline change after 5 weeks for an initial beach fill of $100,000 \mathrm{yd}^{3}$ placed uniformly and nonuniformly with 75,000 (left) and 25,000 (right) $\mathrm{yd}^{3}$ beach fills adjacent to each other.

Figures 9-13 compare inlets with dredging and placement on the beach. An unstructured inlet of $1,000 \mathrm{ft}$ in width was included in these simulations. The initial volumes and equilibrium volumes were equal for all of the inlet shoals. The ebb and flood shoal volumes were $1,000,000 \mathrm{yd}^{3} /$ year while all other shoals (left and right bypassing bar, left and right attachment bar) had a volume of $500,000 \mathrm{yd}^{3} /$ year. In Figure 9, seven different variations of beach fills and dredging are 
compared after a 10-year simulation. Except for the beach fill-only case (in dark green), 100,000 $\mathrm{yd}^{3}$ is removed from the ebb shoal at the beginning of the simulation. The red line represents the case where the sand is removed from the model. In all other cases, the sand is placed either updrift or downdrift of the inlet. When the material is placed 2 miles updrift (to the left; pink) of the inlet, most of the material remains updrift after 10 years although a small percentage will move into or bypass the inlet. A smaller portion of the sand would remain updrift of the inlet if larger waves were used. When the sand is placed 5 miles to the right of the inlet, the beach fill has no impact on shoreline change within approximately 2 miles of the inlet. When a beach fill is placed adjacent to or very near the inlet, the shoreline does not erode nearly as much downdrift as the no-fill alternative, but the maximum shoreline advance is less than the alternatives where the beach fills were placed farther from the inlet. While not shown, the location of the beach fill also has an impact on how quickly the ebb shoal will recover. Note that this model simulation uses unidirectional waves $\left(15^{\circ}\right.$ shore normal), and as a result, a significant downdrift response is illustrated by the extreme erosion adjacent and to the right of the inlet.

Figure 10 compares cases where $20,000 \mathrm{yd}^{3}$ were removed from the ebb shoal every other year, and in beach placement cases, 20,000 $\mathrm{yd}^{3}$ were filled at each dredging interval. The results are very similar to those shown in Figure 9, but the total shoreline advance from a beach fill is slightly larger and more concentrated at the location of placement in Figure 10. This effect is to be expected because it was noted in the first example that a $100,000 \mathrm{yd}^{3}$ placement at the beginning of the simulation spread farther along the $x$-axis than $20,000 \mathrm{yd}^{3}$ placed every other year (Figure 6).

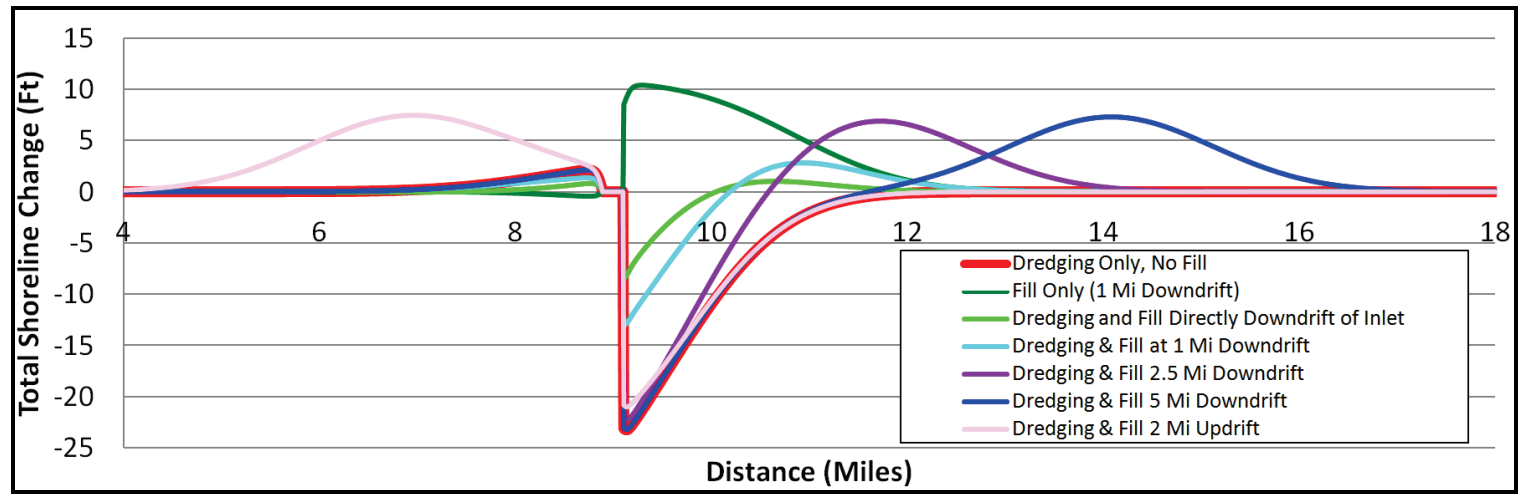

Figure 9. Total shoreline change after 10 years with initial dredging of $100,000 \mathrm{yd}^{3}$ from ebb shoal and placement at various locations.

Figure 11 compares shoreline change after 10 years for alternatives where $100,000 \mathrm{yd}^{3}$ or 20,000 $\mathrm{yd}^{3}$ every other year were dredged from the ebb shoal and removed from the model or placed 1 or 5 miles downdrift. These same alternatives were shown in the previous figures, but it is beneficial to show the two dredging alternatives together. From approximately 10 to 11 miles alongshore, the shoreline accretes slightly more when $20,000 \mathrm{yd}^{3}$ is dredged every other year and placed 1 mile downdrift than an initial dredging and placement of $100,000 \mathrm{yd}^{3}$. Very close to the inlet, the initial $100,000 \mathrm{yd}^{3}$ placement at 1 mile downdrift of the inlet results in slightly less erosion than the placement of $20,000 \mathrm{yd}^{3}$ every 2 years. 


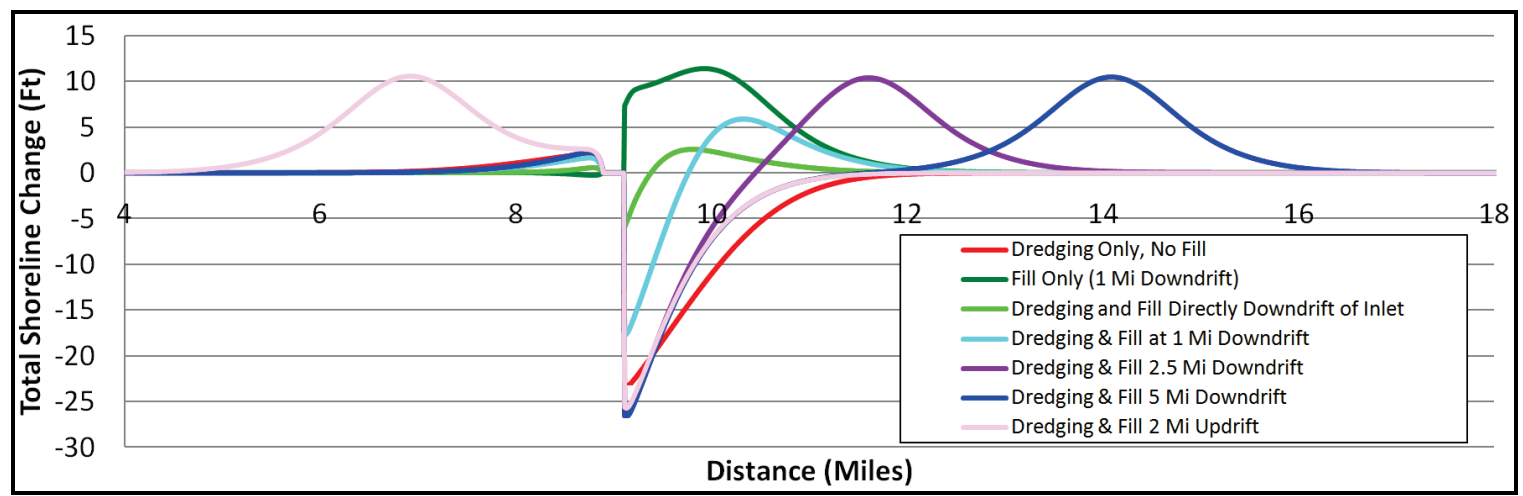

Figure 10. Total shoreline change after 10 years when dredging of 20,000 $\mathrm{yd}^{3}$ from ebb shoal every other year and placement at various locations.

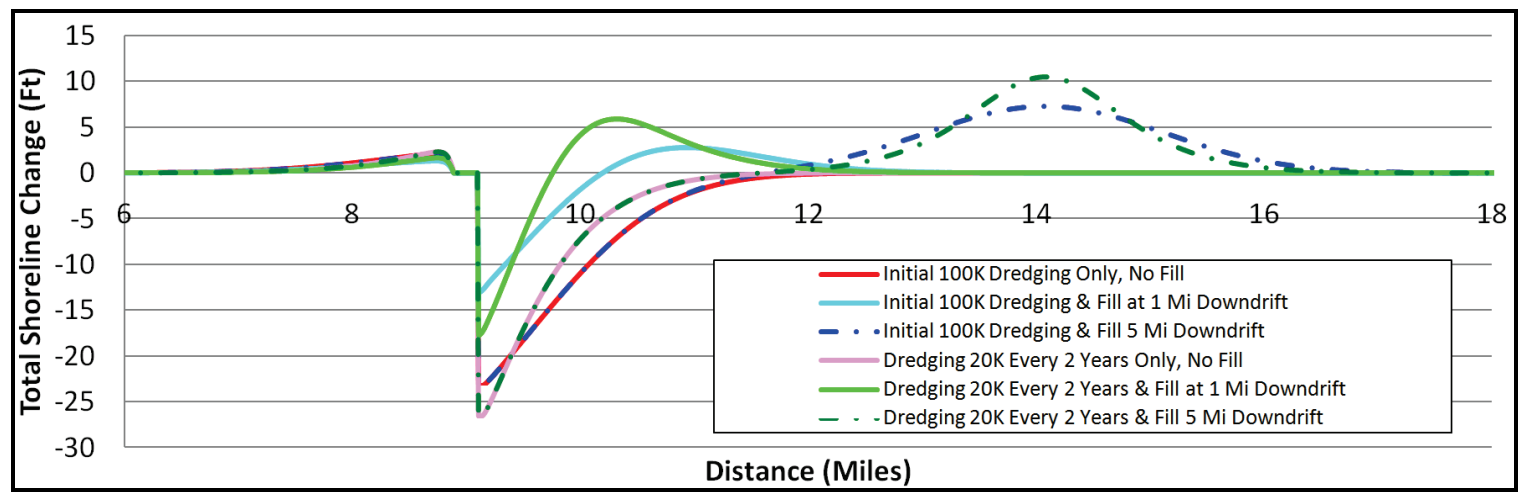

Figure 11. Total shoreline change after 10 years when dredging either $100,000 \mathrm{yd}^{3}$ or $20,000 \mathrm{yd}^{3}$ every other year from the ebb shoal. Material is placed either updrift or downdrift of inlet.

Figure 12 compares shoreline change after 10 years after dredging the ebb shoal, flood shoal, or right bypassing bar (removing the material entirely from the model) to dredging each shoal and placing the same volume of material 1 mile downdrift. The dredging and placement volume is $100,000 \mathrm{yd}^{3}$ at the beginning of the simulation for all cases. In general, removing sand from the system will result in greater overall shoreline retreat. When the ebb shoal is dredged, the shoreline recession is slightly greater than in cases where the same amount of material is dredged from the flood shoal. When the right bypassing bar is dredged, the shoreline recession immediately adjacent to the inlet is almost identical to the case where the flood shoal is dredged. However, farther away from the inlet, the cases where the right bypassing bar is dredged result in slightly more erosion than the other cases at distances more than a mile away from the inlet. 


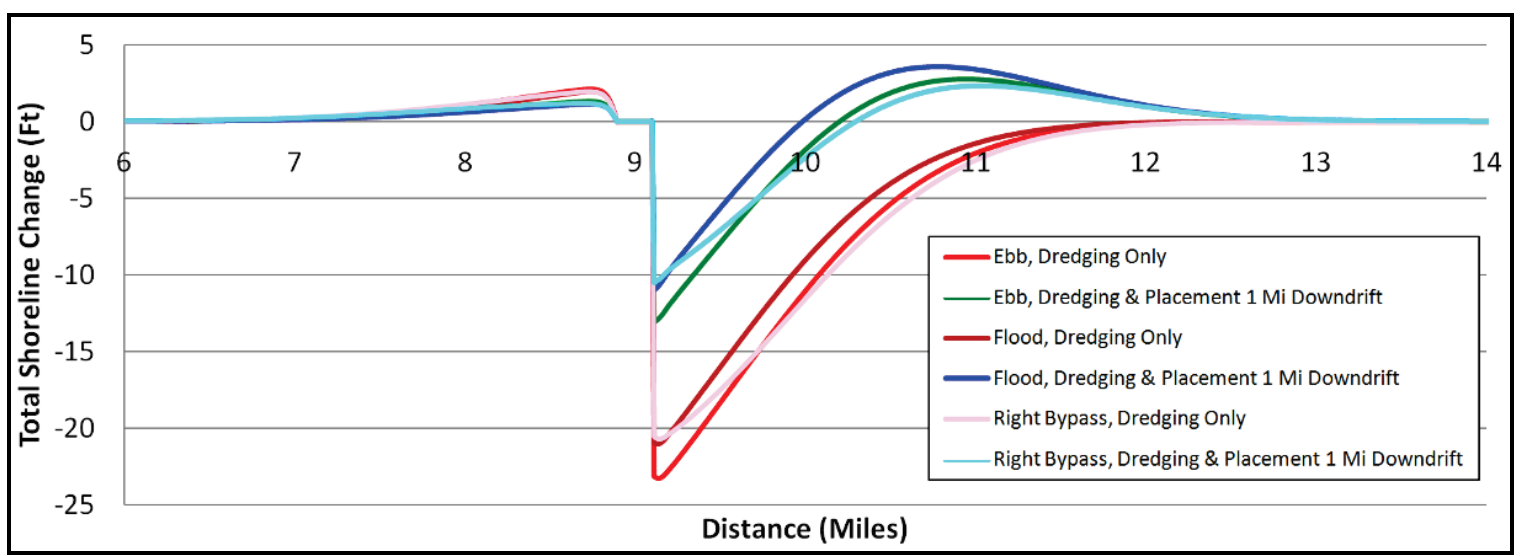

Figure 12. Total shoreline change after 10 years when dredging either $100,000 \mathrm{yd}^{3}$ from the ebb shoal, flood shoal, or right bypassing bar. Material is removed or placed 1 mile downdrift.

The calculated shorelines are to be expected based on the methodology employed in the Inlet Reservoir Model (IRM), which assumes that if a jetty is not present at an inlet, all of the sand transported off of the adjacent island will enter the inlet system (Kraus 2002). Depending on how full the ebb and flood shoal reservoirs are with respect to equilibrium, a portion of the incoming sediment will fill the ebb shoal while another portion will fill the inlet channel (which will feed into the ebb and flood shoals). Only a portion of the transported sediment will leave the inlet system and be transported farther down the beach, unless the system is at equilibrium. Further details about the IRM formulation within GenCade can be found in Frey et al. $(2012,2014)$. Figure 13 shows the results when the ebb, flood, or right bypass bar is dredged 20,000 yd ${ }^{3}$ evey other year. The results are similar, but the effects of the beach fill and dredging are more local, which is to be expected due to the timing of the beach fills and dredging.

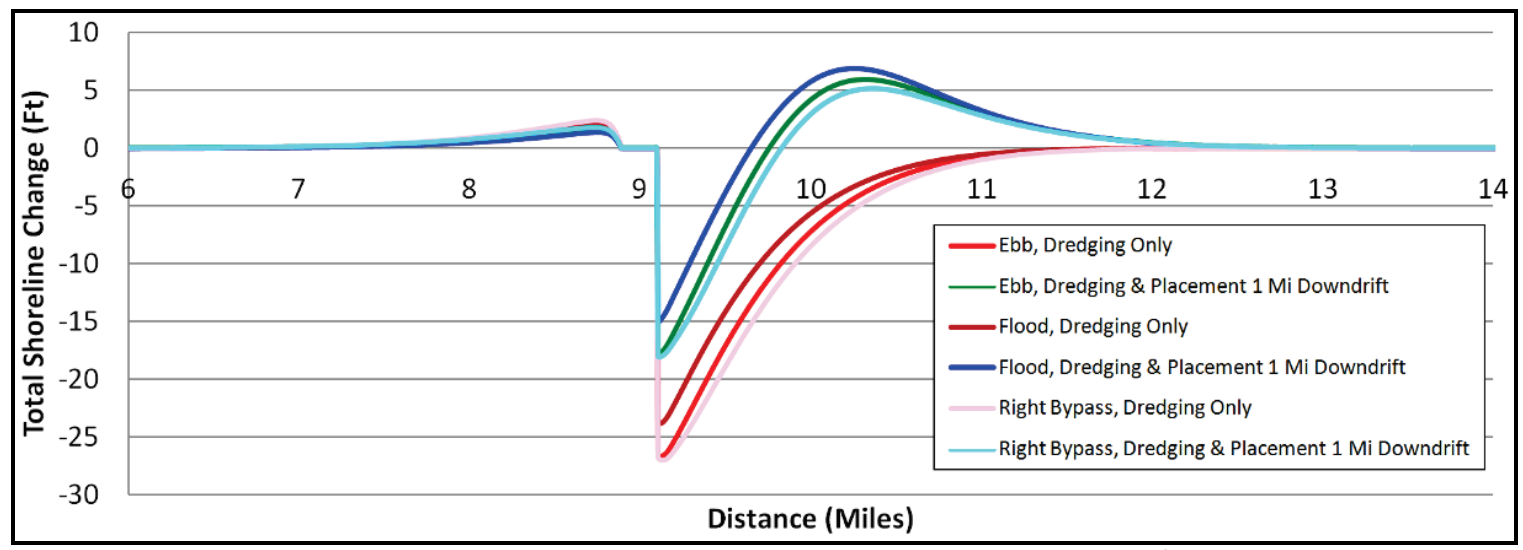

Figure 13. Total shoreline change after 10 years when dredging $20,000 \mathrm{yd}^{3}$ every other year from the ebb shoal, flood shoal, or right bypassing bar. Material is removed or placed 1 mile downdrift.

Shoal evolution through time is shown in Figure 14. After 10 years, dredging $100,000 \mathrm{yd}^{3}$ at the beginning or $20,000 \mathrm{yd}^{3}$ every other year does not make much difference in terms of the right bypass bar volume. The flood shoal recovers slightly less than the ebb shoal when dredged due to the apportionment of transported sediment it received in the IRM. The only alternative where 
the shoal does not fully recover after 10 years is when the flood shoal is dredged $20,000 \mathrm{yd}^{3}$ every other year. The final shoal volume is approximately $960,000 \mathrm{yd}^{3}$.

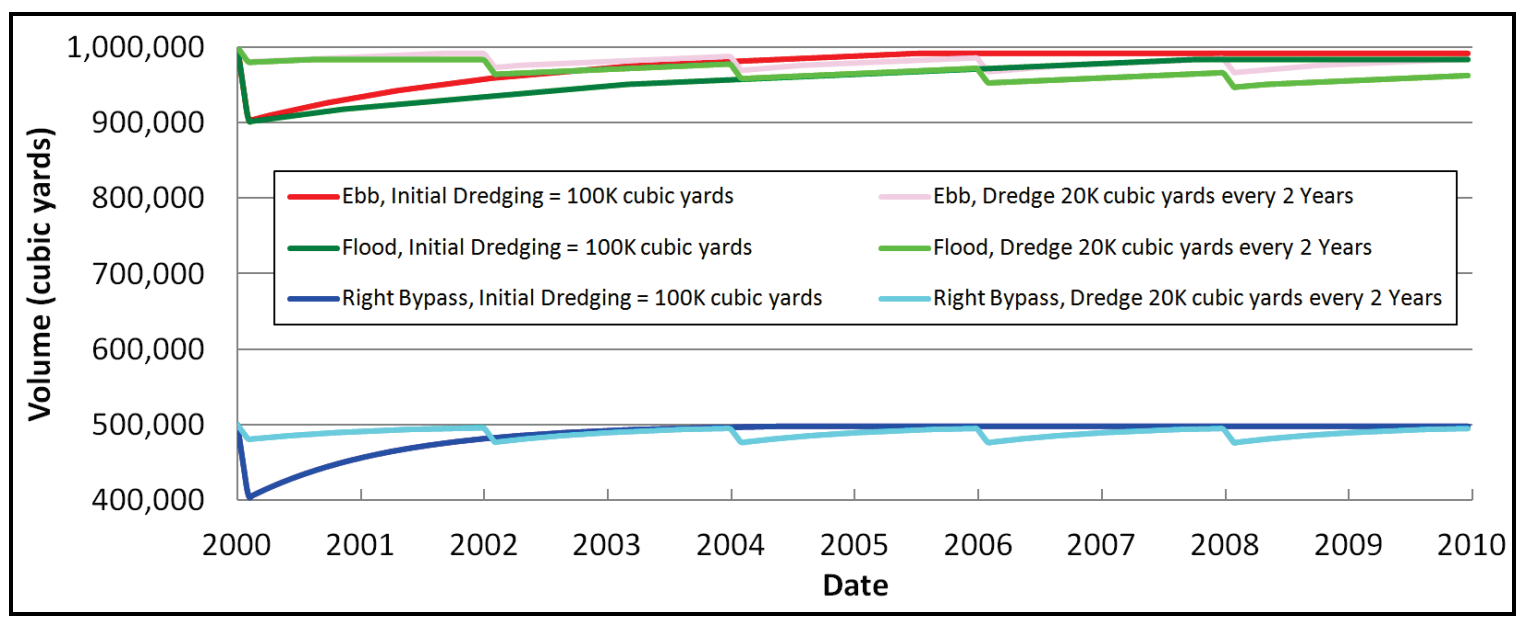

Figure 14. Shoal volume evolution through time.

Each of these plots demonstrates the type of analyses that can be conducted with GenCade. A typical study might compare dredging different volumes from different shoals or placing material in various locations along the shore. Since GenCade is a very quick model to run, a modeler can run many alternatives and compare the results within the same day. The alternatives can give the modeler a better idea of which options to pursue in more detail and could pave the way for improved RSM practices. Knowing that many District projects involve dredging and beach placement, it was important to illustrate how GenCade can help District employees make decisions with regards to long-term planning horizons on the temporal and spatial scales of regional sediment transport. However, please note the examples shown here were simple, idealized simulations, and calibration was not conducted. When completing a typical study, it is necessary to complete the calibration and validation process before comparing beach fill and dredging alternatives.

PRESENT LIMITATIONS: There are three limitations that may impact the types of alternatives that can be modeled in GenCade. First, $\mathrm{D}_{50}$ for beach fills and the sand removed from a shoal must be the same as the user-specified Median Grain Size. Dredging a shoal with finer material or placing much coarser sand on the beach than the median beach grain size do not meet the present model requirements. Second, nourishments must occur on the beach; there is no option for a nearshore placement. This is an area of future research. Finally, there is presently not an option to dredge in the inlet channel. Since this is a major source of dredging, there are plans to initiate formulation of options to handle inlet channel dredging in FY16-17. This CHETN shows that dredging the same volume from one shoal compared to another does not make much difference in the shoreline change near the inlet.

CONCLUSIONS AND SUMMARY: This CHETN provides further information on dredging events and beach fills in GenCade. Basic theory and setup of beach fills and dredging events are shown. Several idealized cases with various beach fills and dredging events are analyzed and compared to demonstrate the impacts of each event and describe the types of applications which can be modeled with GenCade. After reviewing this CHETN, a GenCade user should have a better understanding of how the model responds to different inputs (beach fill and dredging 
volumes, locations, and timing during the simulation) and should be able to apply this knowledge to future studies.

POINT OF CONTACT: This CHETN was prepared as part of the Coastal Inlets Research Program (CIRP) and was written by Ashley E. Frey (Ashley.E.Frey@usace.army.mil, voice: 601-634-2006) of the U.S. Army Engineer Research and Development Center (ERDC), Coastal and Hydraulics Laboratory (CHL). Dr. Sung-Chan Kim and Dr. David King provided peerreview of this publication. This technical note should be referenced as follows:

Frey, A. E. 2016. Applications of dredging and beach fills in GenCade. ERDC/CHL CHETN-IV-109 Vicksburg, MS: U.S. Army Engineer Research and Development Center.

An electronic copy of this CHETN is available from http://cirp.usace.army.mil/wiki/Publications.

\section{REFERENCES}

Connell, K. J., and N. C. Kraus. 2006. Cascade version 1: User's guide. ERDC-TN-SWWRP-06-5. Vicksburg, MS: U.S. Army Engineer Research and Development Center.

Frey, A. E., K. J. Connell, H. Hanson, M. Larson, R. C. Thomas, S. Munger, and A. Zundel. 2012. GenCade version 1 model theory and user's guide. ERDC/CHL TR-12-25. Vicksburg, MS: U.S. Army Engineer Research and Development Center.

Frey, A. E., D. B. King, and S. Munger. 2014. Recommendations and requirements for GenCade simulations. ERDC/CHL TR-14-6. Vicksburg, MS: U.S. Army Engineer Research and Development Center.

Hanson, H., and N. C. Kraus. 1989. GENESIS: Generalized model for simulating shoreline change, report 1. Technical Report CERC-89-19. Vicksburg, MS: U.S. Army Engineer Waterways Experiment Station.

Kraus, N. C. 2002. Reservoir model for calculating natural sand bypassing and change in volume of ebb-tidal shoals, part I: Description. ERDC/CHL CHETN-IV-39. Vicksburg, MS: U.S. Army Engineer Research and Development Center.

Larson, M., N. C. Kraus, and H. Hanson. 2003. Simulation of regional longshore sediment transport and coastal evolution - The Cascade model. In Proc. $28^{\text {th }}$ Coastal Engineering Conference, ASCE, $2,612-2,624$.

Munger, S., and A. E. Frey. 2015. GenCade version 1 quick-start guide: How to start a successful GenCade Project. ERDC/CHL SR-15-1.Vicksburg, MS: U.S. Army Engineer Research and Development Center.

NOTE: The contents of this technical note are not to be used for advertising, publication, or promotional purposes. Citation of trade names does not constitute an official endorsement or approval of the use of such products. 